\title{
REVISITING THE BIPOLAR DISTINCTION IN THE CHARACTERISATION OF ARMED CONFLICTS
}

\author{
by W Ochieng*
}

\section{Introduction}

Since the Geneva Conventions, the architecture of International Humanitarian Law (IHL) has been founded upon a distinction between international armed conflict and non-international armed conflict. Today, this claim stands to be revisited since international and noninternational armed conflicts are no longer strict organising frameworks for the categorisation of rules of armed conflicts. This is seen in that over fifty years ago, when the four Geneva Conventions were negotiated, the principles of sovereignty and non-intervention were the cornerstones of international law and while their force today is still apparent, the interdependence of states, and global concerns such as terrorism and the commission of widespread human rights violations have eroded the traditional inviolability of borders. The dichotomy in humanitarian law is as implausible today as it is also fundamentally unworkable given the current conditions of conflicts.

This dualist conception is no longer adequate to deal with current features of armed conflict, which do not fit neatly into the two categories and frequently contain mixed elements which thus make the task of classification highly complex. The codification of customary rules of international humanitarian law has narrowed the grounds on which the distinctions are predicated. In addition, the two regimes apply simultaneously on multiple situations. Moreover, the question of contemporary armed conflicts raises serious doubts as to whether the traditional understanding of international law still suffices to explain the complexities of modern day armed conflicts.

This essay seeks to offer a different perspective on armed conflicts by suggesting a systematic rethinking of the categorisation of conflict. It argues that some of the dilemmas of contemporary conflicts may be attenuated by a new conceptualisation of this bipolar distinction namely a need for a unitary conception of armed conflict.

* Walter Khobe Ochieng, LLB Candidate, Moi University Kenya. 


\section{The dualist conception of the law of armed conflict.}

IHL is largely codified in treaties, in particular the four 1949 Geneva Conventions $^{1}$ (the Conventions) and the two 1977 additional protocols (the Protocols). ${ }^{2}$ These instruments apply only to armed conflicts. The Conventions and Protocols establish a strict distinction between international and non-international armed conflicts, with the latter being governed by less detailed and less protective rules.

In the normal course of events, the term 'international armed conflict' refers to a conflict between two or more states. ${ }^{3}$ Common Article 2 of the Geneva Conventions of 1949 gives an insight into the definition of an international armed conflict by stating that the Conventions should apply:

To all cases of declared war or of any other armed conflict which may arise between two or more of the High Contracting Parties, even if the state of war is not recognised by one of them and to 'all cases of partial or total occupation', even if such occupation does not meet armed resistance.

In contrast, a non-international armed conflict is a confrontation between the existing governmental authority and groups of persons subordinate to this authority. This is carried out by force of arms within national territory and it reaches the magnitude of an armed riot or a civil war. ${ }^{4}$ Common Article 3 of the Geneva Conventions ${ }^{5}$ and

Convention [No I] for the Amelioration of the Condition of the Wounded and Sick in Armed forces in the Field, 12 August 1949, 75 UNTS 31-83; Convention [No II] for the Amelioration of the Condition of the Wounded, Sick and Shipwrecked members of Armed Forces at Sea, 12 August 1949, 75 UNTS 85-133; Convention [No III] relative to the Treatment of Prisoners of War, 12 August 1949, 75 UNTS 135-285 and Convention [No IV] relative to the protection of Civilian persons in Time of War, 12 August 1949, 75 UNTS 287-417.

2 Protocol [No I] Additional to the Geneva Conventions of 12 august 1949 relating to the protection of Victims of International Armed Conflicts, 8 June 1977, 1125 UNTS 3-434; Additional Protocol [No II] to the Geneva Conventions of 12 August 1949 , and relating to the protection of Victims of Non-international Armed Conflicts, 8 June 1977, 1125 UNTS 609-699.

3 Art 1 para 4 Additional Protocol (AP) I, however, provides that the term includes: '... armed conflicts in which peoples fight against colonial domination and alien occupation and against racist regimes in the exercise of their right to selfdetermination, as enshrined in the Charter of the United Nations and the Declaration on Principles of International Law concerning Friendly Relations and

4 Co-operation among states in accordance with the Charter of the United Nations.' In a non-international armed conflict each party shall be bound to apply, as a minimum, the fundamental humanitarian provisions of international law embodied in the four 1949 Geneva Conventions (Common Art 3), the 1954 Cultural Property Convention (art 19) and the 1977 Additional Protocol II.

5 Contains a series of rudimentary provisions dealing with minimum rights and duties, such as the requirements that those hors de combat be treated humanely and that the wounded and sick be collected and cared for, and the prohibition against murder, torture, hostage taking, humiliating and degrading treatment, and the passing of sentences and carrying out executions without a fair trial. 
AP II which is far more detailed, ${ }^{6}$ are the two instruments which expressly apply to non-international armed conflicts.

In two respects, AP II does not go as far as Common Article 3. First, whereas article 3 applies to any 'armed conflict not of an international character occurring in the territory of one of the High Contracting parties', AP II applies only to armed conflicts taking place in the territory of a high contracting party between its armed forces and dissident armed forces or other organised armed groups which, under responsible command, exercise such control over a part of the High Contracting party's territory as to enable them to carry out sustained and concerted military operations and to implement the Protocol. $^{7}$

In addition, article I(2) provides that: 'This Protocol shall not apply to situations of internal disturbances and tensions, such as riots, isolated and sporadic acts of violence and other acts of a similar nature, as not being armed conflicts.' AP II will, it seems, be applicable between the government of a state and a rebel movement, in contrast, article 3 is broad enough to cover a conflict between different rebel movements competing for power within a state where the government is not involved as such or has ceased to exist.

Although internal conflicts are, in principle, subject to a different and more limited legal regime than that which applies to an international armed conflict, it is possible that some or all of the law of international armed conflicts may become applicable in a conflict which was originally classified as internal. This is achievable through Common Article 3 which encourages parties to an internal conflict to conclude special agreements to bring other provisions of the Geneva Conventions into force between them. In addition, foreign intervention may have the effect of giving an internal conflict an international character, at least in some of its aspects. Thus, the Commission of Experts established by the United Nations Security Council to investigate allegations of war crimes in the conflicts in the former Yugoslavia stated in its report to the UN Secretary General that, although the classification of the various conflicts was a difficult matter:

The Commission is of the opinion ... that the character and complexity of the armed conflicts concerned, combined with the web of agreements on humanitarian issues the parties have concluded among themselves, justify an approach whereby it applies the law applicable in

6 D Forsythe 'Legal management of internal war: The 1977 protocol on noninternational armed conflicts' (1978) 72 American Journal of International Law 272.

7 Art I, para I AP II. 
international armed conflicts to the entirety of the armed conflicts in the territory of the former Yugoslavia. ${ }^{8}$

\section{The challenges posed by contemporary conflicts to international humanitarian law}

\subsection{The rise of non-international armed conflicts}

The post-World War II era has seen an increase in the frequency of non-international and internal armed conflicts. ${ }^{9}$ In addition to an increase in frequency, non-international armed conflicts also consume more lives, more resources and have been more protracted than contemporary international armed conflicts has been seen. ${ }^{10}$ Post-WWII era war casualties have also been more likely to be civilians rather than combatants.

Moreover, these non-international armed conflicts often failed to remain purely internal. Frequently, intervening factors, such as third state interference, would act to 'internationalise' the conflict, and turn an non-international armed conflict into what has been termed 'internationalised' armed conflict. ${ }^{11}$

\subsection{The emergence of a hybrid internationalised armed conflict}

Internationalised armed conflicts usually demonstrate characteristics of both internal and international armed conflicts, such as when two non-state groups fight one another within the boundaries of a single state, or where an insurgent group fights against its government, but one of the parties, usually the insurgent group, is equipped or otherwise assisted by a third state. ${ }^{12}$

Contemporary armed conflicts often pass through stages at which they are international and stages at which they are non-international. This type of conflict raises special problems regarding the temporal scope of application in the Geneva Conventions. Thus the phenomenon of internationalised conflicts which embody both

Interim Report of the Commission of Experts established pursuant to Security Council Resolution 780 (1992), UN Doc. S/25274 (26 January 1993), para 45. However, the Report of the Secretary General pursuant to para 2 of the Security Council Resolution 808 (1993), UN Doc. S/25704 (3 May 1993), containing a draft statute for an International War Crimes Tribunal adopts a more cautious approach.

9 Gleditsch and others 'Armed conflict 1946 -2001: A new dataset' (2002) 39 Journal of Peace Research 615.

10 S Tharoor 'The future of civil conflict' (1999) 16 World Policy Journal 8-9.

11 RR Baxter 'The evolving laws of war' (1972) Military Law Review 5.

12 The military intervention by Rwanda and Uganda in the Democratic Republic of Congo is a good illustration of an internationalised conflict. 
international and internal elements presents a very real obstacle to the continuation of the dualistic regulation.

\subsection{The place of transnational terrorist groups in international humanitarian law}

Different legal regimes apply to transnational terrorist groups, given the reality of splitting up various facets of the conflict to be international armed conflict and others as non-international armed conflicts, which may not be entirely satisfactory. Some aspects of the terrorist and counter-terror operations are non-international armed conflicts but there are issues on which the law, as it stands, is not adequate.

When and where terrorism and counter-terrorism operations manifest themselves, in either form of armed conflict, international humanitarian law applies. However, it is not always easy to categorise outbreaks of violence as international or non-international armed conflict, or to identify the status of the actors involved. This is because such armed conflicts span the territories of several states even though the armed hostilities are not international. This can make it difficult to identify the relevant normative framework to regulate the conduct of affected parties. ${ }^{13}$

The norms prohibiting acts of terrorism in non-international armed conflict are identical to those applicable in international armed conflict. Article 3 Common to the four Geneva Conventions prohibits acts of terrorism. ${ }^{14}$ Protocol II reaffirms and develops these rules. ${ }^{15}$ But neither article 3 nor Protocol II has a provision similar to article 35 of Protocol I, which, for international armed conflict, codifies the long established principle that parties to an armed conflict are not free to choose the methods or means of combat of their liking and in particular that those weapons which cause superfluous injury or unnecessary suffering are outlawed.

However, the ICTY has concluded that the more egregious crimes committed in a non-international armed conflict are to be considered

13 RA Barnes 'Of vanishing points and paradoxes: Terrorism and international humanitarian law' (2005) International Conflict and Security Law 129-159.

14 The article without actually using the words 'terrorism' prohibits the following acts at any time and in any place: (a) violence to life and person, in particular murder of all kinds, mutilation, cruel treatment and torture; (b) taking of hostages and (c) outrages upon personal dignity, in particular humiliating and degrading treatment.

15 Under the heading 'Humane treatment' of those who do not, or no longer, take part in military operations, art 4, para 2(d) even condemns 'acts of terrorism' outright as contrary to the law. Moreover, Additional Protocol II also codifies standards for the conduct of military operations in internal conflicts. 
as international crimes. ${ }^{16}$ This means that acts of terrorism committed in a non-international armed conflict may indeed be equated with grave breaches, as defined by the 1949 Geneva Conventions.

As for customary international law, a recent comprehensive survey undertaken under the auspices of the International Committee of the Red Cross (ICRC) has uncovered a large body of customary rules, the majority of which are claimed to apply to both international and non-international armed conflicts. ${ }^{17}$ It is of note, however, that the study has neither clarified the distinction between international and non-international armed conflicts - in particular cases where a conflict with a non-state actor extends beyond the borders of one state - nor has it defined the lower threshold at which violence amounts to an armed conflict (for non-international armed conflicts).

The Conventions and Protocol I apply to international armed conflicts. Common Article 2 to the Conventions states that they 'shall apply to all cases of declared war or of any other armed conflict which may arise between two or more of the High Contracting Parties.'18 Since only states can be parties to the Conventions and transnational armed groups are not states then it can be posited that the Conventions do not apply to conflicts between states and non-state actors. As for customary international law, there is no indication that the concept of international armed conflict under customary international law is broader. ${ }^{19}$

Some activities of (and against) transnational armed groups are nevertheless covered by the law of international armed conflicts, including all hostilities directed against the armed forces or the territory of one state by forces representing another state or acting de facto under the direction or control of that other state. ${ }^{20} \mathrm{~A}$ transnational group may well be under the direction and control of a state. IHL of international armed conflict will then apply. Similarly, the law of international armed conflicts applies when a state is directing hostilities against a transnational-armed group on the territory of another state without the agreement of the latter.

Therefore international rules do apply in the trial of a person prosecuted for a crime committed in a non-international armed conflict. See Prosecutor $v$ Tadic, (Appeal Judgment) IT-94-1-A, ICTY, 15 July 1999.

17 JM Henckaerts \& LD Oswald-Beck (eds) Customary international humanitarian law (2005) 5.

18 Article 2 Common to the Conventions; and art 1(3) of Protocol I refers to this provision, but art 1(4) expands the field of application to national liberation

19 W Lietzau, 'Combating terrorism: Law enforcement or war?' in MN Schmitt \& GL Beruto, (eds) Terrorism and International Law, Challenges and Responses (2002) 80.

Tadic (n 16 above) para 116-144. 
Hostilities between one or several states, on the one side, and a transnational armed group, on the other, which do not qualify under the above-mentioned criteria as international armed conflicts may be non-international armed conflicts covered by article 3 Common to the four Conventions and by Protocol II. This presupposes, firstly, that the hostilities meet the minimum threshold for a non-international armed conflict and secondly, that every armed conflict not classified as international is perforce a non-international armed conflict, even if it is neither internal nor limited to the territory of one single state.

The question of the extraterritorial application of Common Article 3 , examined in light of the more general evolution in humanitarian law favours the convergence between the law of international armed conflict and the law of non-international armed conflict. A result of this convergence is that individuals involved in a non-international armed conflict can now benefit from many of the protections once available only in the context of inter-state conflicts. In any event, notwithstanding continuing controversy over its content, there seems to be consensus supporting the proposition that the law of noninternational armed conflict applies extraterritorially.

As noted above, demonstrating the applicability of humanitarian law outside of a state's territory is facilitated by the fact that the bulk of the law of armed conflict was designed to apply in an interstate context, assuming that states would be acting on each other's territory. That some of these rules are now deemed to apply even in an internal setting does not lessen the presumption that they will still apply extraterritorially, at least insofar as they consist of prohibitions and do not purport to impose obligations on third states. ${ }^{21}$

If a transnational armed group is a party to an armed conflict, it has to respect the whole of IHL of non-international armed conflict that has been drawing closer in recent years to the full IHL of international armed conflicts. IHL prohibits, in both international and non-international armed conflicts, any act which could be classified as terrorist ${ }^{22}$ in particular attacks against civilians, acts or threats of violence, whose primary purpose is to spread terror among the civilian population, ${ }^{23}$ and indiscriminate attacks. ${ }^{24}$

21 J Cerone 'Jurisdiction and power: The intersection of human rights law \& the law of non-international armed conflict in an extraterritorial context' (2007) 40 Israel Law Review 2.

22 HP Gasser 'Acts of terror, terrorism and international humanitarian law,' (2002) 847 International Review of the Red Cross 556 and Marco Sass'oli 'International humanitarian law and terrorism' in Wilkinson and Steward (eds) Contemporary research on Terrorism (1987) 470-472.

23 See art 51(2) of Protocol I, art 13(2) of Protocol II, and corresponding rule of customary IHL (see Rules 1 and 2 of the ICRC Study (n 17 above) para 3-11)

24 See art 51(4) and (5) of Protocol I, for international armed conflicts and Rules 1114 of the ICRC Study (n 17 above) para 37-50, for all armed conflicts. 
To sum up, it can safely be said that the prohibition of recourse to terrorist acts is as firmly anchored in the law applicable in noninternational armed conflict as it is in rules governing international armed conflict. It is arguable that IHL, as it stands, was developed at another time and is not adequate for the new challenges raised by the contemporary kind of conflict with transnational groups. The law should therefore be adapted to new realities. There is a need to strengthen the mechanisms of implementation geared towards armed groups and this could be done without distinction between the characterisations of armed conflict.

\subsection{New methods of enforcement of the Geneva Conventions}

The Geneva Conventions also introduced universal jurisdiction for 'grave breaches' of the Conventions. Grave breaches are those violations of the Geneva Conventions that are considered especially egregious and are considered to be of such 'gravity and magnitude that they warrant their universal prosecution and repression.'25 'Grave breaches' are crimes committed against those persons and objects designated by the Conventions as specially protected. ${ }^{26}$ Such offences are perceived as attacks on international order.

The principle of universal jurisdiction allows any state to bring to trial a person or persons accused of committing certain crimes against international law, regardless of the location of commission of the crime against international law, or the nationality of the victim or perpetrator. By implementing a system of universal jurisdiction, the hope is that such crimes are punished. ${ }^{27}$

\subsection{Non-traditional tactics in international hostilities}

Finally, contemporary conflicts often involve the use of nontraditional war tactics that may require a reassessment of characterisation. Contemporary armed conflicts are being fought in multiple ways, not only by conventional armed forces but also by tactics typically not associated with armed conflicts including: intelligence and law enforcement action, economic and financial

Attorney General of Israel v Eichmann 196136 ILR 18, 50 (District Court of Jerusalem); affirmed in Attorney General of Israel v Eichmann 196236 ILR 2777, 282-83 (Supreme Court of Israel).

26 These include persons hors de combat, the wounded, sick or shipwrecked, prisoners of war and civilians subject to the territorial control of the detaining power or under the belligerent occupation of an occupying power. Objects protected under the Conventions include medical transports and medical units, non-defended localities and demilitarised zones and objects of cultural, historical or spiritual importance.

27 O Swaak-Goldman 'Recent developments in international criminal law: Trying to stay afloat between scylla and charybdis' (2005) 54 International Comparative Law Quarterly 697. 
sanctions, and special operations that may continue long after the conclusion of any significant troop engagement. ${ }^{28}$ In view of these emerging tactics, the difficulty emerges where answering whether internationalisation of an armed conflict accrues to a foreign state aiding in such supportive roles but not engaging in conventional warfare.

\subsection{Developments in treaty law}

A move towards extending treaties on international humanitarian law to cover internal as well as international conflicts has become apparent in recent years. The Amended Protocol II of 1996 to the UN Weapons Convention applies to non-international armed conflicts, ${ }^{29}$ as does the 1997 Ottawa Convention on the prohibition of AntiPersonnel Mines. ${ }^{30}$ Additionally, the ambit of the 1999 Second Hague Protocol for the Protection of Cultural Property in the Event of Armed Conflict encompasses non-international armed conflicts. ${ }^{31}$

The broad acceptance of these Conventions indicates that at the very least, the use of poison, poisoned weapons or asphyxiating gases should be criminalised in all armed conflicts. Recent developments such as the Blinding Laser Weapons Protocol ${ }^{32}$ and Amended Protocol II to the Certain Conventional Weapons Convention ${ }^{33}$ contains prohibitions and restrictions on the use of mines and other devices, and applies to non-international armed conflict as well as international armed conflict. ${ }^{34}$ These Conventions take into account new developments in international law thus the same philosophy should be extended to international humanitarian law.

Indeed, the convergence of the law of armed conflict is demonstrated by the continued inclusion in $\mathrm{IHL}$ treaties of the Martens Clause. All four of the 1949 Conventions, ${ }^{35}$ as well as both the

The temporal scope of application of international humanitarian law in contemporary conflicts' (2003) International Humanitarian Law Research Initiative 9.

29 Art 1(2) Amended Protocol II of 1996

30 the unconditional language of article 1'. See A Roberts \& $R$ Guelff Documents on the laws of war (2000) 646.

31 Art 22 Second Hague Protocol of 1999.

32 Protocol IV on Blinding Laser Weapons of 1995

33 Convention on Prohibition or Restrictions on the Use of Certain Conventional Weapons Which May be Deemed to be Excessively Injurious or to Have Indiscriminate Effects, 1342 UNTS 137.

34 Amended Protocol on Prohibitions or Restrictions on the Use of Mines, 35 ILM 1206.

35 GC I, art 63, para 4; GC II, art 62, para 4; GC III, art 142, para 4; and GC IV, art 158 , para 4. 
Protocols, ${ }^{36}$ included the Martens Clause $^{37}$ in their final adopted drafts, again restating the importance of the place of the principles of humanity, the dictates of public conscience, and the laws and customs of nations, in determining permissible conduct in all armed conflicts.

\subsection{Codification of customary international humanitarian law}

Since the Conventions apply as treaties in almost any international armed conflict, the question of whether their provisions have achieved the status of customary international law is significant in two aspects. Firstly, in that the decision of the International Court of Justice in Nicaragua $v$ USA ${ }^{38}$ shows that an international tribunal may sometimes be able to apply the provisions of customary international law even though it lacks the competence to apply the provisions of a multilateral treaty. Secondly, in dualist states ${ }^{39}$ treaties do not form part of national legislation and cannot be applied by national courts, whereas national courts can and do apply rules of customary international law. ${ }^{40}$ It seems likely that most of the provisions of the Conventions, if not all, would now be regarded as declaratory of customary international law. ${ }^{41}$

Most of the rules of customary IHL, particularly the parts stemming from the Conventions and Protocol II, apply evenly to all types of conflicts. ${ }^{42}$ Though there are few treaties that address noninternational conflict, ${ }^{43}$ the ICRC has determined that there are 133 rules of customary IHL that govern both international and noninternational conflict in an identical fashion; another nine that govern international conflict and that 'arguably' also govern noninternational conflict; and four rules which are similar, but not identical, in governing the two types of conflict. ${ }^{44}$ Only twelve of the 161 rules promulgated by the ICRC apply exclusively to international conflict. ${ }^{45}$

Art 1(2) of Protocol I and in the Preamble to Protocol II. The Martens Clause is also included in paragraph 5 of the preamble of the Conventional Weapons Convention.

37 In 1899, Fyodor Martens laid down the following principle for cases not covered by humanitarian law: '... Civilians and combatants remain under the protection and authority of the principles of international law derived from established custom, from the principles of humanity and from the dictates of public conscience.'

38 ICJ (1986) Reports 14.

39 Noticeably many commonwealth countries as well as Israel.

40 T Meron Human rights and humanitarian norms as customary international law (1989) 3-78.

41 As above.

42 ICRC Study (n 17 above).

43 As above.

44 n 17 above, 198-212.

45 That leaves three rules which are only applicable in non-international conflict. 
Although the Additional Protocols of 1977 have not yet achieved the near-universal acceptance achieved by the 1949 Geneva Conventions, many provisions of AP I are declaratory of customary international law thus applicable in all armed conflicts. ${ }^{46}$ Even those provisions of AP I, which have not yet achieved the status of rules of customary international law, have influenced public opinion and the perceptions of states as to what is permissible in conflict.

There is an undoubted move towards extending the provisions of law applicable in international armed conflicts to internal conflicts. The Tadic Interlocutory Appeal Decision has been instrumental in this regard. ${ }^{47}$ This decision confirmed the customary law status of common article $3,{ }^{48}$ the 'Core of Additional Protocol II of 1977' and article 19 of the Hague Convention for the Protection of Cultural Property in the Event of Armed conflict of $1954 .{ }^{49}$ Furthermore, the Tribunal asserted that customary rules governing internal conflicts included the protection of civilians from hostilities, in particular from indiscriminate attacks, protection of civilian objects, in particular cultural property, protection of all those who do not (or no longer) take active part in hostilities, as well as prohibition of means of warfare proscribed in international armed conflicts and ban of certain methods of conducting hostilities. ${ }^{50}$ As regards customary humanitarian law, the pronouncements of the ICTY are highly authoritative and progressive.

Aside from the progressive advancement of customary law there are further endeavours which symbolise the growing demand for a more unitary system of law such as the 'Declaration of Turku' which seeks to establish a minimum set of humanitarian standards which would apply in all armed conflicts. ${ }^{51}$ Furthermore, the 1999 Secretary General's Bulletin on Observance by United Nations (UN) Forces of International Humanitarian Law obliges all UN forces involved in peacekeeping or enforcement missions to respect fundamental norms of humanitarian law regardless of the characterisation of the conflict. $^{52}$

D Fleck (ed) The Handbook of Humanitarian law in Armed conflicts (1995) 497 As above, 96-127.

The customary law status of common article 3 was pronounced previously by the International Court of Justice, Case Concerning Military and Paramilitary Activities In and Against Nicaragua (Merits), Nicaragua $v$ United States (n 38 above) para 218.

Tadic (n 16 above) para 98.

As above, para 127.

UN Sub-Commission on Prevention of Discrimination and Protection of Minorities Minimum Humanitarian Standards 51st Session UN Doc. E/CN 4/1995/116 (1995). See also the Seoul Resolution on the Relevance of International Humanitarian Law in Today's Armed Conflicts Res/Seoul 42/SP/1 (2003).

Secretary General's Bulletin on Observance by UN Forces of International Humanitarian Law UN Doc ST/SGB/999/13 (1999). 


\section{Conclusion}

The effect of a rapidly globalising world has confirmed that a state's interests are hardly confined within its territories and thus countries are more prone to be affected by the goings on in the territories of its neighbours. This has led to the emergence of a pattern whereby internal conflicts often grow to international ones, and international conflicts spill over into internal ones.

Whilst there has been progress in ensuring that the rules of international humanitarian law applicable are no longer a 'skeleton compared with those which apply to international conflicts, ' 53 there still remains a difference in the law applicable in the two situations nevertheless. The Tadic Interlocutory Appeal Decision summarised this, emphasising the limitations in the extension of the law governing international armed conflicts to internal conflicts. ${ }^{54}$ The Appeal Chamber stated that:

only a number of rules and principles governing international armed conflicts have gradually been extended to apply to internal conflicts', and that 'this extension has not taken place in the form of a full and mechanical transplant of those rules to internal conflicts; rather, the general essence of those rules, and not the detailed regulation they may contain, has become applicable to internal conflicts. ${ }^{55}$

Policies should be amended to encourage compliance with all rules of international humanitarian law in the conduct of any armed conflict, irrespective of whether that conflict is characterised as internal or international. Compliance with the full body of rules of international humanitarian law in non-international conflicts undoubtedly presents practical problems, but it serves not only humanitarian interests but also operational requirements. ${ }^{56}$

The law regulating both types of conflicts needs also to be characterised by the drafting of a single international instrument that would embrace the humanitarian notion that victims in all situations of armed conflict, irrespective of the nature of the latter, are subject to the same suffering and should be helped in the same way.

C Greenwood 'International humanitarian law and united nations military operations,' (1998) 1 YIHL 3-9 Tadic (n 16 above) para 126.

As above.

International Institute for Humanitarian Law, Declaration on the Rules of International Humanitarian Law Governing the Conduct of Hostilities in NonInternational Armed Conflicts, IRRC, Sep -Oct 1990, 404-8. 